\title{
Immunomodulation and smart materials for maxillofacial tissue engineering
}

\author{
Seong-Gon Kim
}

Maxillofacial area is the most interesting part of tissue engineering because there are most type of tissues including the skin, mucosa, gland, tooth, and bone. As the age of patients who want to receive maxillofacial reconstruction is increased, immunomodulation is getting much more attention. Particularly, medication associated disturbance in bone biology and diabetes are major challenging diseases for the success of the reconstruction.

Recently, review showed current level of immunomodulation [1]. Though there are many types of immune cells, macrophages are considered as the most important one because they stay in the tissue and orchestrate all regeneration process. Thereafter, macrophages are the target of immunomodulation. Grossly, macrophages are classified as M1 and M2 type [1]. M1-type macrophages are mainly responsible for the inflammation and the defense against infection. M2-type macrophages are important in the regeneration and remodeling. The main purpose of immunomodulation is timely transition from inflammatory phase to regenerative phase. The examples of immunomodulation are (1) modification of surface, (2) change of pore size, and (3) adding bioactive ingredients.

Modulation of physical properties is simple and widely used particularly in the development of dental implant and bone graft. However, they have limitation. For example, if the surface is encapsulated with dense fibrotic tissue, it cannot induce phase transition to M2. However, adding bioactive ingredients asks much more sophisticated strategy. Bioactive ingredients should be delivered timely and properly. For the purpose-derived optimal delivery, smart materials are required [2]. Inflammatory tissue has lower $\mathrm{pH}$ compared to regenerative tissue. If the materials are designed to be $\mathrm{pH}$ responded manner, optimal delivery can be achieved.

Among M2 inducer, 4-hexylresorcinol (4HR) received attention recently [3]. 4HR has been used for antiseptics and food ingredient. 4HR can induce M2-type macrophage

\section{Correspondence: kimsg@gwnu.ac.kr}

Department of Oral and Maxillofacial Surgery, College of Dentistry,

Gangneung-Wonju National University, Gangneung 28644, Republic of Korea when administered. As 4HR has long alkyl chain, it can be incorporated into any polymer easily. M2-type macrophages can secrete many types of proteolytic enzymes. If $4 \mathrm{HR}$ incorporated into any scaffold designed to be degraded by proteolysis, it can control the speed of the scaffold degradation $[4,5]$. As M2-type macrophages have antiinflammatory properties, $4 \mathrm{HR}$ can suppress graft-induced inflammatory reaction, too.

The development of ideal graft material is still an important issue in the maxillofacial reconstructive surgery. There is a definite point for the successful treatment where cannot be overcome by surgical technique. That is why surgeons should have interest in the tissue engineering.

\section{Acknowledgements \\ Not applicable.}

\section{Author's contributions}

The author read and approved the final manuscript.

Funding

Not applicable.

\section{Availability of data and materials \\ Not applicable.}

Ethics approval and consent to participate

Not applicable.

Consent for publication

Not applicable.

\section{Competing interests}

The author declares that there are no competing interests.

Received: 7 January 2020

Published online: 12 February 2020

References

1. Chen Z, Klein T, Murray RZ, Crawford R, Chang J, Wu C et al (2016) Osteoimmunomodulation for the development of advanced bone biomaterials. Mater Today 19:304-321

2. Lu Y, Aimetti AA, Langer R, Gu Z (2017) Bioresponsive materials. Nat Rev Mater 2:16075

3. Jo YY, Kim DW, Choi JY, Kim SG (2019) 4-Hexylresorcinol and silk sericin increase the expression of vascular endothelial growth factor via different pathways. Sci Rep 9:3448 
4. Jo YY, Kweon H, Kim DW, Kim MK, Kim SG, Kim JY et al (2017) Accelerated biodegradation of silk sutures through matrix metalloproteinase activation by incorporating 4-hexylresorcinol. Sci Rep 7:42441

5. Kweon H, Kim SG, Choi JY (2014) Inhibition of foreign body giant cell formation by 4- hexylresorcinol through suppression of diacylglycerol kinase delta gene expression. Biomaterials 35:8576-8584

\section{Publisher's Note}

Springer Nature remains neutral with regard to jurisdictional claims in published maps and institutional affiliations.

\section{Submit your manuscript to a SpringerOpen ${ }^{\odot}$ journal and benefit from:}

- Convenient online submission

- Rigorous peer review

- Open access: articles freely available online

- High visibility within the field

- Retaining the copyright to your article

Submit your next manuscript at $\boldsymbol{\wedge}$ springeropen.com 